\title{
Kajian Optimalisasi Aset Milik PT. Perkebunan Nusantara XII (Persero)
}

\author{
Dwi Aryani Suryaningrum ${ }^{1}$, Dyah Puspasari ${ }^{2}$ \\ Politeknik LPP Yogyakarta ${ }^{12}$ \\ Email: Anisurya@Yahoo.Com
}

https://doi.org/10.30741/adv.v3i2.490

\section{N F O A R T I K E L}

Tanggal masuk :

10 November 2019

Tanggal Revisi :

12 Desember 2019

Tanggal Diterima :

31 Desember 2019

\section{A B S T R A K}

Pertumbuhan ekonomi kota Surabaya mendorong semakin berkembangnya pula usaha komersial salah satunya adalah usaha properti. Namun melihat adanya keterbatasan lahan yang semakin besar di Surabaya, maka alternatifnya mengoptimalkan asset yang telah ada. Optimalisasi tersebut berupa penggunaan lahan dengan mendirikan sebuah properti yang dapat memberikan keuntungan sehingga nilai pasar dari suatu lahan menjadi tinggi. Bangunan Mess PT. Perkebunan Nusantara XII (Persero) yang berlokasi di Jalan Embong Tanjung No.17 Surabaya mempunyai luas 1.388 $\mathrm{m}^{2}$ dan berada di area yang berpotensi untuk dikembangkan menjadi alternatif properti komersial seperti apartemen, hotel, perkantoran, dan pertokoan. Penentuan nilai Bangunan Mess tersebut bergantung pada penggunaan lahan, untuk itu perlu dilakukan analisa Highest and Best Use (HBU), yaitu secara fisik dimungkinkan, secara hukum diijinkan, layak secara finansial, dan memiliki produktivitas maksimum. Hasil yang diperoleh dalam penelitian ini dilihat dari aspek lahan, lokasi, hokum dan finansial adalah alternatif hotel sebagai penggunaan lahan terbaik yang memiliki nilai lahan tertinggi yaitu sebesar Rp 52.253.874/m2.

Kata Kunci : Optimalisasi, Aset, Highest and Best Use

\begin{abstract}
A B S T R A C T
The economic growth of Surabaya also encourages the development of commercial businesses, one of which is the property business. But seeing the increasingly limited land in Surabaya, then the alternative is to optimize existing assets. The optimization is in the form of land use by establishing a property that can provide benefits so that the market value of a land becomes high. Mess Building PT. Perkebunan Nusantara XII (Persero) which is located on Jalan Embong Tanjung No.17 Surabaya has an area of $1,388 \mathrm{~m} 2$ and is in an area that has the potential to be developed into an alternative commercial property such as apartments, hotels, offices, and shops. The determination of the value of the Mess Building depends on land use, for this reason it is necessary to conduct a Highest and Best Use (HBU) analysis, which is physically possible, legally permitted, financially feasible, and has maximum productivity. The results obtained in this study were seen from the aspects of land, location, legal and financial alternatives of the hotel as the best land use that has the highest land value of IDR 52,253,874 $/ \mathrm{m} 2$.
\end{abstract}

Keywords: Optimalization, Assets, Highest and Best Use 


\section{PENDAHULUAN}

Bagi suatu perusahaan, aset tanah maupun bangunan merupakan sumber daya yang dapat memberikan kontribusi baik secara finansial maupun secara non-finansial. Pemanfaatan aset dilakukan agar aset tersebut tidak menjadi beban biaya, namun diharapkan memberikan keuntungan terhadap perusahaan. Aset perusahaan merupakan potensi ekonomi yang bermakna adanya manfaat finansial dan ekonomi yang bisa diperoleh pada masa yang akan datang. Keberadaan aset perusahaan adakalanya tidak termanfaatkan secara baik dan maksimal sehingga usaha pemanfaaan dan optimalisasi aset merupakan keharusan agar dapat menjadi salah satu sumber penghasil profit bagi perusahaan. Optimalisasi asset dapat dilakukan dengan dua cara, yaitu studi optimalisasi asset dan perantara investasi. Studi optimalisasi asset dapat dilakukan antara lain dengan identifikasi asset, pengembangan basis data asset, studi Highest and Best Use atas asset, dan pengembangan strategi optimalisasi asset (Siregar, 2004:523). Metode Highest and Best Use pernah dilakukan dalam penelitian Mubayyinah dan Cristian Utomo (2012) yang meneliti untuk property Lahan "X" di Surabaya. Serta juga pernah digunakan dalam penelitian Akmaluddin dan Cristian Utomo (2013) dalam penelitiannya di Gedung di Surabaya.

Pertumbuhan ekonomi kota Surabaya, maupun Propinsi Jawa Timur yang cukup pesat serta mobilitas penduduk, pendatang, maupun pebisnis ke kota Surabaya yang cepat. sangat mendukung perkembangan dari usaha property komersiil baik berupa perkantoran maupun hotel. Meskipun pertumbuhan hotel dan property baru cukup pesat, namun pasar potensial di Surabaya dan sekitarnya masih cukup menjanjikan. Apalagi dengan berkembangnya industri wisata maupun industri perdagangan seperti kota besar lainnya, maupun bertumbuhnya bandara udara baik internasional maupun lokal sehingga memungkinkan bertumbuhnya wisatawan mancanegara maupun local, serta para pebisnis untuk berkunjung ke Surabaya. Penelitian ini memfokuskan pada optimalisasi asset yang dimiliki oleh PTPN XII yang merupakan asset BUMN.

\section{METODE PENELITIAN}

Penelitian ini menggunakan prinsip penilaian penggunaan tertinggi dan terbaik (Highest and Best Use) untuk menghasilkan nilai tertinggi dari lahan milik PT Perkebunan Nusantara XII (Persero) di Jalan Embong Tanjung no 17, Surabaya. Metode yang digunakan pada analisis optimalisasi aset ini adalah Highest and Best Use yang didefinisikan sebagai kajian penggunaan yang mungkin dan memungkinkan serta diijinkan (legally permissible) dari suatu tanah kosong (vacant land) atau tanah yang sudah dibangun (improvement) yang mana secara fisik memungkinkan (physically posible) serta layak secara keuangan (financially feasible) dan menghasilkan nilai tertinggi bagi pemiliknya (maximum value). Konsep Highest and Best Use (HBU) adalah penggunaan yang paling memungkinkan dan diizinkan dari suatu lahan kosong atau lahan yang sudah dibangun, yang mana secara fisik memungkinkan, didukung atau dibenarkan oleh peraturan, layak secara keuangan dan menghasilkan nilai tertinggi. HBU dari suatu properti tidak tergantung dari analisis subjektif, siapa pemilik, pengembang maupun penilai properti sekalipun, tetapi HBU ini tercipta akibat adanya kekuatan persaingan pada pasar dimana properti tersebut terletak.

Dalam suatu penilaian HBU terdapat empat kriteria atau persyaratan yang harus dipenuhi, antara lain : 1. Memungkinkan secara fisik (physically possible) atau aspek fisik. Dalam aspek fisik hal yang harus ditinjau untuk lahan kosong adalah ukuran, bentuk tanah, luas, ketinggian serta kontur tanah. Sedangkan pada lahan yang telah terdapat properti diatasnya tergantung pada pertimbangan luas, desain dan kondisi dari properti. Pada lokasi yang memiliki bentuk tanah, kontur yang tidak teratur akan menyulitkan pembuatan perencanaan pembangunan properti dilokasi tersebut. Ukuran, bentuk, daerah, kemiringan, asessibilitas serta resiko alami daerah bencana seperti banjir atau gempa bumi akan berdampak terhadap penggunaan suatu lahan tersebut. 2. Diizinkan oleh peraturan yang ada (legal permissible). Kelayakan secara legal diperlukan dalam analisa Highest and Best Use untuk menghindari adanya penyalahgunaan fungsi guna lahan seperti yang telah ditetapkan menurut peraturan oleh pemerintah. Hal yang perlu dikaji dalam aspek legal yaitu peruntukan (zonning), aturan mengenai bangunan, bangunan bersejarah, dan peraturan-peraturan 
yang berkenaan dengan lingkungan. Bila tidak terdapat private restrictions, kegunaan properti biasanya ditentukan oleh zoningnya yang berhubungan dengan pilihan-pilihan penggunaan tanah yang telah ditetapkan oleh pemerintah. Peraturan - peraturan bangunan yang perlu diperhatikan antara lain batasan ketinggian bangunan, garis sempadan, rasio luas tanah yang boleh didirikan bangunan.

Analisis kelayakan keuangan ini dilakukan dengan memperhatikan tingkat hunian (occupation rate), biaya operasi, pendapatan bersih (net operating income) dan tingkat pengembalian. Dasar penghitungan pendapatan dan biaya dengan penghitungan net cashflow yang telah didiskontokan. Analisis yang digunakan seperti pada analisis investasi yaitu nilai Net Present Value (NPV), Internal Rate of Return (IRR) serta Payback Period-nya. Nilai properti dapat diketahui dari hasil perhitungan Net Operating Income (NOI) dibagi dengan tingkat kapitalisasi. Tingkat kapitalisasi didapat dari safe rate ditambah atau dikurang dengan tingkat resiko. Tingkat kapitalisasi ini dapat dihitung dengan rata-rata suku Bungan deposito di beberapa bank ternama ditambah dengan tingkat risiko perusahaan, atau dihitung dengan metode Weight Average Cost of Capital (WACC). $\mathrm{V}=\mathrm{NOI} / \mathrm{R}, \mathrm{NOI}=\mathrm{PK}-\mathrm{TK}-\mathrm{O}$. Keterangan, $\mathrm{V}$ : Nilai Properti, NOI : Net Operating Income, $\mathrm{R}$ : Capitalization Rate, PK : Pendapatan Kotor, TK : Tingkat Resiko, O : Biaya Operasional. Menghasilkan penghasilan secara maksimum (maximally productive). Setelah ditinjau layak secara keuangan, maka kegunaan yang menghasilkan nilai lahan residual yang tertinggi merupakan penggunaan tertinggi dan terbaik .

\section{HASIL DAN PEMBAHASAN}

Dalam penetapan jenis alternatif properti dilakukan dengan metode observasi lapangan terhadap properti disekitar lahan. Dari observasi tersebut diperoleh jenis properti komersial yang berkembang dan memungkinkan untuk didirikan pada lahan penelitian yaitu hotel, apartemen, perkantoran dan pertokoan. Namun demikian dengan melihat luasan dan bentuk lahan yang ada, penelitian yang memungkinkan adalah usaha hotel dan perkantoran. Aspek fisik yang ditinjau meliputi bentuk dan ukuran lahan, utilitas umum, serta aksesibilitas dari lahan yang ditinjau. 1. Profil lahan. Berdasarkan data survei yang didapatkan, lahan obyek tinjauan secara umum berbentuk persegi panjang. Lebar muka lahan adalah 22,5 m, panjang ke belakang $61,7 \mathrm{~m}$, serta total luasan lahan adalah $1388 \mathrm{~m}^{2}$. Pada lahan tinjauan telah ada bangunan rumah tinggal berlantai satu dengan luas dasar $634 \mathrm{~m}^{2}$. Pemanfaatan bangunan kurang lebih $46 \%$ dari lahan yang ada. Bangunan masih menyisakan ruang kosong di bagian halaman depan bangunan seluas $304 \mathrm{~m}^{2}$ serta di bagian halaman belakang seluas $287 \mathrm{~m}^{2}$. Pemanfaatan ruang kosong bagian depan dan belakang bangunan selama ini dipakai sebagai taman dan tempat parkir kendaraan. Bentuk lahan tinjauan berbentuk persegi panjang dengan lebar muka berkisar $40 \%$ dari panjangnya, sehingga relatif memberikan kemudahan dalam proses perencanaan pembangunan properti. Bentuk tersebut didukung pula oleh jenis kontur tanah tinjauan yang secara fisik tergolong datar. 2. Utilitas Umum. Seputar lokasi Jl. Embong Tanjung merupakan kawasan yang mengalami pertumbuhan perdagangan maupun jasa. Sebagai kawasan bertumbuh, daerah ini memiliki dukungan dan ketersediaan utilitas seperti jaringan air bersih, listrik, dan komunikasi. 3. Aksesibilitas. Obyek tinjauan berada di Jalan Embong Tanjung yang merupakan jalan kolektor menuju Jalan Jenderal Sudirman sebagai jalan arteri sekunder. Jalan Embong Tanjung merupakan bagian dari pola grid sistem jaringan jalan kota dari fungsi arteri Jalan Jenderal Sudirman ke fungsi kolektor Jalan Kayun dan Jalan Pemuda sehingga memiliki aksesibilitas yang cukup baik. Jalan Embong Tanjung relatif dekat dan memiliki aksesibilitas yang baik dengan Stasiun Gubeng sebagai salah satu simpul moda transportasi umum antar kota. Tersedia transportasi umum untuk menuju daerah obyek tinjauan, baik menggunakan bus kota maupun taxi.

Analisis aspek legal didasarkan pada peraturan zonning dan RTRK yang berlaku untuk obyek tinjauan. Berdasarkan Rencana Tata Ruang Wilayah (RTRW) Surabaya tahun 2013, Aset yang terletak di Jalan Embong Tanjung no 17, kecamatan Genteng, Surabaya, termasuk dalam Unit Pengembangan VI Tunjungan yang meliputi wilayah Kecamatan Simokerto , Kecamatan 
Bubutan, Kecamatan Genteng dan Kecamatan Tegalsari. Adapun fungsi kegiatan dan pusat pertumbuhan pada Unit Pengembangan (UP) VI Tunjungan adalah Permukiman, Pemerintahan, Perdagangan dan Jasa dengan pusat pertumbuhan berada di Kawasan Tunjungan. Dengan demikian asset di Jalan Embong Tanjung 17, dapat dimanfaatkan sebagai bangunan komersial berupa, perhotelan, perkantoran, pertokoan, pergudangan dll. Dengan mempertimbangkan luas bangunan dan lokasi asset berada, maka alternative terbaik untuk bangunan komersial yang dapat dibangun adalah perhotelan atau perkantoran. Sedangkan berdasarkan Peraturan Walikota Surabaya nomor 39 tahun 2012, tentang Pedoman dan Standar Teknis untuk Pelayanan Pemanfaatan Ruang, dapat disusun asumsi dan perhitungan yang dipakai sebagai berikut, a) Garis Sempadan Depan yang digunakan adalah 10 m. b) Garis Sempadan Samping Kiri dan kanan yang digunakan masing-masing adalah $3 \mathrm{~m}$. c) Garis Sempadan Belakang yang digunakan adalah $4 \mathrm{~m}$. d) Luas Dasar Bangunan setelah dikurangi garis sempadan adalah: 47,5 m X 16,5 m= $784 \mathrm{~m}^{2}$. e) Koefisien Dasar Bangunan $(\mathrm{KDB})=$ Luas Lantai Dasar : Luas Seluruh Lahan = $787: 1388=56,7$ $\%$, nilai ini masih < KDB Maksimum (60\%). f) Koefisien Lantai Bangunan (KLB) lokasi tinjauan adalah $1500 \%$. g) Luas lantai maksimum yang diijinkan $=$ Luas Lahan X KLB $=1388$ X 1500\%= $20.820 \mathrm{~m}^{2}$ Jumlah lantai maksimum yang dapat didirikan adalah = Luas lantai bangunan maksimum : Luas dasar bangunan maksimum $=20.820: 784=26$ lantai. Dalam analisis ini jumlah lantai yang digunakan adalah 12 lantai dari 26 lantai yang masih dapat dibangun, sehingga luas total lantai $=9.024 \mathrm{~m}^{2} . \mathrm{h}$ ) Luas Lahan Sisa yang tidak terbangun $=$ Luas total lahan - Luas dasar bangunan $=1388-787=601 \mathrm{~m}^{2}$ Koefisien Daerah Hijau $(\mathrm{KDH})=$ Luas lahan sisa tidak terbangun : Luas total lahan $=601: 1388=43,3 \%$, dengan melihat $\mathrm{KDH}$ minimum lokasi tinjauan sebesar $20 \%$, maka nilai $\mathrm{KD}=43,3 \%$ masih memenuhi persyaratan.

Tabel 1. Ketentuan Luas Bangunan dari Aspek Legal

\begin{tabular}{|c|c|c|c|c|c|}
\hline No & Uraian & Satuan & \multicolumn{2}{|c|}{ Ukuran } & Catatan \\
\hline 1 & Garis Sempa dan Depan & $\mathrm{m}$ & & 10 & \\
\hline 2 & Garis Sempa dan Samping & $\mathrm{m}$ & & 3 & \\
\hline 3 & Garis Sempa dan Belakang & $\mathrm{m}$ & & 4 & \\
\hline 4 & $\begin{array}{l}\text { Luas dasar bangunan stl } \\
\text { dikurangi garis sempadan }\end{array}$ & $\mathrm{m} 2$ & $\begin{array}{l}47.5 x \\
16.5=\end{array}$ & 784 & \\
\hline 5 & $\begin{array}{l}\text { Koefisien Dasar Bangunan } \\
\text { (KDB) }\end{array}$ & & & $56.47 \%$ & $\begin{array}{l}\text { KDB maks } \\
60 \%\end{array}$ \\
\hline 6 & Luas lantai maksimum diijinkan & & & 20,820 & $\begin{array}{c}\text { Koefisien } \\
\text { Lantai } \\
\text { Bangunan } \\
\text { (KLB) } 1500 \%\end{array}$ \\
\hline 7 & Jumlah Lantai maksimum & & & 26.56 & \\
\hline 8 & Koefisien Daerah Hijau (KDH) & & & $43.53 \%$ & $\begin{array}{c}\mathrm{KDH} \\
\text { minimum } 20 \%\end{array}$ \\
\hline
\end{tabular}

Berdasarkan hasil analisis dan pembahasan dari beberapa segi pada aspek legal dapat disimpulkan bahwa lahan pada lokasi tinjauan seluas $1388 \mathrm{~m}^{2}$ dapat didirikan bangunan komersial dengan jumlah 12 lantai, dengan luas dasar $784 \mathrm{~m}^{2}$ dan luas lantai bangunan $9.024 \mathrm{~m}^{2}$.

Dalam aspek finansial dilakukan beberapa analisis penilaian property baik dari aspek nilai lahan maupun dari aspek nilai usaha. Berdasarkan penilaian dari KJPP Sih Wiryadi \& Rekan diperoleh nilai lahan sekarang sebagai berikut: 
Tabel 2. Penilaian Aset oleh KJPP Sih Wiryadi \& Rekan

\begin{tabular}{lccr}
\hline \multicolumn{1}{c}{ Uraian } & No sertifikat & Luas $(\mathbf{m} 2)$ & \multicolumn{1}{c}{ Nilai pasar } \\
\hline Tanah & SHGB 856 & 1388 & $18,778,252,000.00$ \\
Bangunan I & & 620 & $1,082,900,000.00$ \\
Bangunan II & & 55 & $118,875,000.00$ \\
\hline Jumlah & & & $19,980,027,000.00$ \\
\hline
\end{tabular}

Laporan penilaian asset oleh KJPP Sih Wiryadi \& Rekan akan dilaporkan tersendiri. Untuk perhitungan analisis usaha perhotelan dan perkantoran dipergunakan data sekunder untuk menentukan asumsi dan beberapa dasar perhitungan. Data yang dipergunakan untuk dasar perhitungan investasi maupun revenue diperoleh dari tariff dan data gedung perkantoran dan hotel disekitar kawasan Tunjungan dan jlan Pemuda. Data asumsi yang telah diolah oleh peneliti sebagai berikut:

Tabel 3. Asumsi Operasional

\begin{tabular}{clccc}
\hline No & \multicolumn{1}{c}{ Uraian } & Satuan & Hotel & Perkantoran \\
\hline 1 & Nilai investasi bangunan/m2 & $\mathrm{Rp} / \mathrm{m} 2$ & $5,500,000$ & $3,750,000$ \\
2 & Tarif sewa Kantor & $\mathrm{Rp} / \mathrm{m} 2 / \mathrm{bln}$ & & 100,000 \\
3 & Average room rate & $\mathrm{Rp}$ & 356,370 & \\
4 & Occupancy Rate & $\%$ & $64.5 \%$ & \\
5 & Jumlah kamar hotel & $\mathrm{kamar}$ & 155 & \\
6 & Luas bangunan & $\mathrm{m} 2$ & 8,592 & 9,024 \\
7 & luas bangunan disewakan & $\mathrm{m} 2$ & 4,992 & 6,422 \\
8 & jumlah lantai termasuk basement & lantai & 12 & 12 \\
\hline
\end{tabular}

Dengan mempertimbangkan aspek skala ekonomis untuk pembangunan perhotelan, dan aspek legal yang telah dibahas sebelumnya, maka sebagai dasar perhitungan analisis optimalisasi asset dengan metode HBU dipergunakan asumsi akan dibangun hotel maupun perkantoran dengan jumlah lantai termasuk basement sebesar 12 lantai. Adapun asumsi financial yang dipergunakan untuk menghitung analisis financial adalah sebagai berikut:

Tabel 4. Asumsi Finansial

\begin{tabular}{clcc}
\hline No & \multicolumn{1}{c}{ Uraian } & Satuan & Asumsi \\
\hline 1 & Suku bunga Pinjaman & $\%$ & 9.75 \\
2 & Beta Properti & & 1.29 \\
3 & FR 0070, JT 15 Maret 2024 & $\%$ & $8.80 \%$ \\
4 & $\begin{array}{l}\text { Risk Premium Indonesia } \\
\text { (Darmodaran) }\end{array}$ & $\%$ & $9.13 \%$ \\
5 & Nilai tukar dollar (US \$ 1) & Rp & $10,500.00$ \\
\hline
\end{tabular}

Berdasarkan asumsi di atas dihasilkan Weight Average Cost of Capital (WACC) yang akan dipergunakan untuk penghitungan analisis investasi maupun dasar pengambilan keputusan lainnya. Dasar perhitungan nilai investasi bangunan perkantoran dengan menggunakan ukuran lantai dasar $752 \mathrm{~m} 2$, dengan jumlah lantai 12, termasuk basement. Total luasan bangunan menjadi sebesar $9.024 \mathrm{~m} 2$ dan total luas bangunan yang disewakan sebesar $6.422 \mathrm{~m} 2$. Adapun rincian luasan bangunan dan fungsinya dapat dilihat pada table 5 sebagai berikut: 
Tabel 5. Penghitungan Luas Bangunan Perkantoran dan Fungsinya

\begin{tabular}{|c|c|c|c|}
\hline Lantai & Fungsi & Ukuran & Luas (m2) \\
\hline $\begin{array}{l}\text { Lantai } \\
\text { Dasar }\end{array}$ & Parkir, generator, ruang ibadah & $47 \mathrm{~m} \times 16 \mathrm{~m}$ & 752 \\
\hline \multirow[t]{9}{*}{ Lantai I } & Lift & $6 \mathrm{~m} \times 2 \mathrm{~m}$ & 12 \\
\hline & Tangga Darurat & $3 \mathrm{mX} 4 \mathrm{~m}$ & 12 \\
\hline & Toilet & $10 \mathrm{~m} \mathrm{X} 3 \mathrm{~m}$ & 30 \\
\hline & koridor & $2 \mathrm{~m} \mathrm{X} 47 \mathrm{~m}$ & 94 \\
\hline & Pantry dan gudang & $4 \mathrm{~m} \times 8 \mathrm{~m}$ & 32 \\
\hline & Lobby utama & $6 \mathrm{mX} 5 \mathrm{~m}$ & 30 \\
\hline & Kantor pengelola & $4 \mathrm{~m} \mathrm{X} 10 \mathrm{~m}$ & 40 \\
\hline & Total & & 250 \\
\hline & Ruangan disewakan & $752 m^{2}-250 m^{2}$ & 502 \\
\hline \multirow[t]{7}{*}{$\begin{array}{l}\text { Lantai II- } \\
\text { XI }\end{array}$} & Lift & $6 \mathrm{mX} 2 \mathrm{~m}$ & 12 \\
\hline & Tangga Darurat & $3 \mathrm{mX} 4 \mathrm{~m}$ & 12 \\
\hline & Toilet & $8 \mathrm{~m} \times 3 \mathrm{~m}$ & 24 \\
\hline & Koridor/Free Area & $2 \mathrm{~m} \mathrm{X} \mathrm{40m}$ & 80 \\
\hline & Pantry dan gudang & $4 \mathrm{~m} \times 8 \mathrm{~m}$ & 32 \\
\hline & Total & & 160 \\
\hline & Ruangan disewakan & $752 m^{2}-180 m^{2}$ & 592 \\
\hline
\end{tabular}

Untuk keperluan pembangunan hotel bintang 3, maka direncanakan adanya 4 tipe kamar hotel yaitu : Suite, Junior Suite, Deluxe dan Superior, dengan luasan kamar masing-masing adalah 48 m2 untuk tipe kamar Suite, 36 m2 untuk tipe kamar Junior Suite, 28 m2 untuk tipe kamar Deluxe, serta $22 \mathrm{~m} 2$ untuk tipe kamar Superior. Perhitungan luasan bangunan dan peruntukannya sebagai berikut: 
Tabel 6. Penghitungan Luas Bangunan Hotel dan Fungsinya

\begin{tabular}{|c|c|c|c|c|c|}
\hline $\begin{array}{l}\text { Nama } \\
\text { Lantai }\end{array}$ & Nama Ruang & $\begin{array}{l}\text { Jumlah } \\
\text { Ruang }\end{array}$ & \multicolumn{2}{|c|}{ Luas } & \multirow{2}{*}{$\begin{array}{c}\text { Luas Total } \\
716\end{array}$} \\
\hline Basement & $\begin{array}{l}\text { Parkir, Generator, } \\
\text { Gudang }\end{array}$ & 1 & 716 & 716 & \\
\hline Lantai 1 & $\begin{array}{l}\text { Main loby, main } \\
\text { restourant dan business } \\
\text { center }\end{array}$ & 1 & 716 & 716 & 716 \\
\hline Lantai 2 & $\begin{array}{l}\text { Service area dan meeting } \\
\text { room }\end{array}$ & 1 & 716 & 716 & 716 \\
\hline Lantai 3 & Hall/Meeting room & 1 & 716 & 716 & 716 \\
\hline \multirow{3}{*}{ Lantai 4} & Kamar Hotel $22 \mathrm{~m}^{2}$ & 16 & 22 & 352 & \\
\hline & Meeting Room & 1 & 240 & 240 & 716 \\
\hline & Koridor dan Lobby & 1 & 124 & 124 & \\
\hline \multirow{3}{*}{ Lantai 5} & Kamar Hotel $22 \mathrm{~m}^{2}$ & 16 & 22 & 352 & \\
\hline & Kamar Hotel $28 \mathrm{~m}^{2}$ & 8 & 28 & 224 & 716 \\
\hline & Koridor dan Lobby & 1 & 140 & 140 & \\
\hline \multirow{3}{*}{ Lantai 6} & Kamar Hotel 22 m2 & 16 & 22 & 352 & \\
\hline & Kamar Hotel $28 \mathrm{~m}^{2}$ & 8 & 28 & 224 & 716 \\
\hline & Koridor dan Lobby & 1 & 140 & 140 & \\
\hline \multirow{3}{*}{ Lantai 7} & Kamar Hotel $22 \mathrm{~m}^{2}$ & 16 & 22 & 352 & \\
\hline & Kamar Hotel $28 \mathrm{~m}^{2}$ & 8 & 28 & 224 & 716 \\
\hline & Koridor dan Lobby & 1 & 140 & 140 & \\
\hline \multirow{3}{*}{ Lantai 8} & Kamar Hotel $22 \mathrm{~m}^{2}$ & 16 & 22 & 352 & \\
\hline & Kamar Hotel $28 \mathrm{~m}^{2}$ & 8 & 28 & 224 & 716 \\
\hline & Koridor dan Lobby & 1 & 140 & 140 & \\
\hline \multirow{3}{*}{ Lantai 9} & Kamar Hotel $22 \mathrm{~m}^{2}$ & 16 & 22 & 352 & \\
\hline & Kamar Hotel $28 \mathrm{~m}^{2}$ & 8 & 28 & 224 & 716 \\
\hline & Koridor dan Lobby & 1 & 140 & 140 & \\
\hline \multirow{4}{*}{ Lantai 10} & Kamar Hotel $28 \mathrm{~m}^{2}$ & 15 & 28 & 420 & \multirow{4}{*}{716} \\
\hline & Kamar Hotel $36 \mathrm{~m}^{2}$ & 2 & 36 & 72 & \\
\hline & Kamar Hotel 48 m $^{2}$ & 2 & 48 & 96 & \\
\hline & Koridor dan Lobby & 1 & 128 & 128 & \\
\hline \multirow{2}{*}{ Lantai 11} & Sky Lounge & 1 & 500 & 500 & \multirow[t]{2}{*}{716} \\
\hline & Koridor dan Lobby & 1 & 216 & 216 & \\
\hline
\end{tabular}

Dari analisis di atas dapat dihasilkan total luas bangunan $6300 \mathrm{~m} 2$, dengan total kamar sebanyak 128 kamar.

Perhitungan investasi berdasarkan perencanaan bangunan dan peruntukannya, dihasilkan nilai investasi masing-masing property sebagai berikut: 
Tabel 7. Nilai Investasi

\begin{tabular}{lcr}
\hline \multicolumn{1}{c}{ Uraian } & Hotel & \multicolumn{1}{c}{ Perkantoran } \\
\hline Bangunan & $47,256,000,000$ & $33,840,000,000$ \\
Public service \& free area & & $1,500,000,000$ \\
Interior room & $7,750,000,000$ & \\
OPERATING office SUPPLIES & $1,750,000,000$ & $1,500,000,000$ \\
Interior supplies & $1,500,000,000$ & $1,000,000,000$ \\
MPL & $2,000,000,000$ & \\
Jumlah Investasi & $60,256,000,000$ & $37,840,000,000$ \\
\end{tabular}

Investasi untuk hotel sebesar Rp 60.256.000,00 dengan jumlah kamar sebanyak 155 kamar, atau harga investasi per kamar sebesar Rp 388.748.387,10. Nilai ini masih dalam kisaran wajar untuk investasi hotel bintang tiga yaitu antara Rp 300.000.000 - Rp 400.000.000.

Dari perhitungan analisis investasi dapat disimpulkan bahwa investasi pada property hotel lebih menguntungkan dari pada investasi pada property perkantoran. Disamping itu, berdasarkan pengamatan di lapangan, lingkungan sekitar jalan Pemuda, Embong Tanjung dan Embong Kenongo telah banyak berdiri bangunan perkantoran baik yang cukup besar seperti Trillium Office and Residence, Wisma BII, dll. Adapun hotel di sekitar masih berupa hotel budget dan hotel melati, maupun hotel yang diperuntukkan para backpacker. Oleh karena itu masih sangat prospektif untuk dibangunnya sebuah hotel untuk memfasilitasi kebutuhan akomodasi tamu bisnis tersebut. Hasil dari analisis investasi sebagai berikut:

Tabel 8. Hasil dari Analisis Investasi

\begin{tabular}{lcc}
\hline \multicolumn{1}{c}{ Uraian } & \multicolumn{2}{c}{ Jenis Alternatif Property } \\
\cline { 2 - 3 } & Hotel & Office Building \\
\hline Net Present Value (NPV) & $19,706,247,401$ & $8,959,377,803.38$ \\
Internal Rate Of Return (IRR) & $19.23 \%$ & $17.67 \%$ \\
Payback Period & 6 Tahun 4 Bulan & 6 Tahun 11 Bulan \\
\hline
\end{tabular}

Alternatif properti yang memiliki nilai aspek fisik, legal, dan finansial positif akan dicari nilai lahan tertinggi melalui uji produktivitas maksimum yaitu dihitung nilai lahan/m2 dengan perumusan: Nilai Properti - Nilai Bangunan/Total Luas Lahan

Nilai properti diasumsikan dari rata-rata net income yang telah didiskontokan. Sedangkan nilai bangunan diasumsikan sebesar nilai investasi bangunan. Alternatif yang memiliki nilai pasar tertinggi merupakan alternatif yang memiliki produktivitas maksimum dan merupakan penggunaan properti yang terbaik.

Tabel 9. Nilai Properti

\begin{tabular}{lcr}
\hline \multirow{2}{*}{ Jenis Kegiatan } & \multicolumn{2}{c}{ Jenis Alternatif Property } \\
\cline { 2 - 3 } & Hotel & Office Building \\
\hline Effective Revenue & $29,226,242,220$ & $13,340,611,830$ \\
Operating Expenses & $13,242,103,750$ & $3,463,940,390$ \\
Net Operating Income & $15,984,138,470$ & $9,876,671,440$ \\
Nilai Property & $132,784,376,954$ & $82,048,066,963$ \\
\hline
\end{tabular}




\begin{tabular}{lrrr} 
& \multicolumn{2}{c}{ Tabel 10 Nilai Lahan } & \\
\hline \multirow{2}{*}{ Jenis Kegiatan } & \multicolumn{1}{c}{ Jenis Alternatif Property } & \multicolumn{1}{c}{ Nilai } \\
\cline { 2 - 4 } & \multicolumn{1}{c}{ Hotel } & Office Building & \multicolumn{1}{c}{$\begin{array}{c}\text { Lahan } \\
\text { Kosong }\end{array}$} \\
\hline Nilai Property & $132,784,376,954$ & $82,048,066,963$ & \\
Nilai Bangunan & $60,256,000,000$ & $37,840,000,000$ & \\
Nilai Lahan & $72,528,376,954$ & $44,208,066,963$ & $18,778,252,000$ \\
Nilai Lahan Per $\mathrm{m}^{2}$ & $52,253,874$ & $31,850,192$ & $13,529,000$ \\
\hline
\end{tabular}

Berdasarkan hasil perhitungan nilai lahan pada Tabel 3.10, nilai lahan tertinggi diperoleh dari alternatif hotel yaitu sebesar Rp 52.253.874/m2, sedangkan nilai lahan dari perkantoran sebesar Rp31.850.192/m2. Nilai lahan ini lebih tinggi daripada lahan dibiarkan kosong yang hanya bernilai Rp 13.529.000/m2. Dari hasil analisis ini dapat disimpulkan bahwa investasi tertinggi adalah pada usaha perhotelan dengan dibuktikan dari aspek financial maupun aspek produktivitas maksimum.

\section{KESIMPULAN}

Berdasarkan pengamatan lapangan, terdapat potensi yang cukup tinggi untuk mengoptimalkan aset PT Perkebunan Nusantara XII (Persero) di Jl Embong Tanjung 17, dimanfaatkan sebagai properti komersial, mengingat terletak pada kawasan perdagangan dan wisata Tunjungan, serta kawasan perkantoran di jalan Pemuda dan sekitarnya. Berdasarkan ketersediaan aksesibilitas dan utilitas, serta letak asset yang berada pada jalan konektor ke jalan Kayun dan jalan Pemuda, maka asset tersebut dapat diusahakan sebagai usaha perhotelan atau perkantoran. Berdasarkan analisis HBU, maka disimpulkan bahwa pemanfaatan asset yang menguntungkan adalah sebagai usaha perhotelan dengan menghasilkan NPV sebesar Rp 19.706.247.401, IRR sebesar 19,23\% dan Payback Period selama 6 tahun 4 bulan. Sedangkan nilai maksimum lahan per m2 adalah Rp 52.253.874. Berdasarkan pengamatan lapangan, pemanfaatan asset sebagai usaha perhotelan lebih menjanjikan karena di daerah tersebut sudah berkembang beberapa usaha perkantoran, maupun beberapa kantor perusahaan besar. Hotel yang sekarang telah ada adalah hotel bintang 5, 4, 3 serta beberapa hotel budget, hotel melati dan hotel untuk para backpacker. Namun demikian masih ada peluang untuk didirikan hotel bintang 3 dengan membidik pasar pebisnis, wisatawan dan untuk kegiatan MICE. Untuk pengelolaan usaha hotel disarankan untuk dikerjasamakan dengan model BOT atau BTO dengan PT Perkebunan Nusantara XII (Persero) memperoleh profit sharing, berupa fixed sharing sebagai kompensasi dari penghapusan asset bangunan, serta incentive sharing yang diperoleh dari pembagian profit sharing berdasarkan Net Operating Profit.

\section{DAFTAR PUSTAKA}

Akmaluddin dan Christiono, U. (2013). Analisis Highest and Best Use (HBU) pada Lahan Jl. Gubeng Raya No. 54 Surabaya, Jurnal Teknik Pomits Vol.2 No.1

Bidaruni, A. dan Christion, U. (2013). Analisis Penggunaan Lahan Kawasan Komersil Perumahan CitraRaya Surabaya dengan Metode Highest and Best Use, Jurnal Teknik Pomits Vol.2 No.2.

Grissom. (1990). Highest and Best Use : The Evolving Paradigm, The Journal of Estate Research, Vol. 5, Number 1.

Lesman, E. (2014). Analisis Highest and Best Use Terhadap Aset Tetap Milik Pemerintah Kabupaten Banyumas (Studi Kasus Lahan di Jalan Dr. Angka, Purwokerto), Tesis, Program Pasca Sarjana Universita Gajah Mada.

Miftahul, M. dan Christiono, U. (2012). Analisis Highest and Best Use (HBU) Lahan "X" Untuk Properti Komersial, Jurnal Teknik Vol.1 No.1.

Minura. (2015). Manajemen Aset Tanah Milik Pemerintah Kabupaten Kuantan Singingi Tahun 2009-2013, Jurnal FISIP Vol.2 No.1. 
Novasari, A. (2015). Analisis Penggunaan Tertinggi dan Terbail Pada Tanah Kosong Milik Pemerintah Provinsi D.I. Yogyakakarta (Studi Tanah di Jalan Jogja - Wates Km. 5.5 Desa Ambarketawang, Gamping), Tesis, Program Pasca Sarjana Universita Gajah Mada.

Riza. (2014). Optimalisasi Aset Tanah Bekas Gedung Bioskop Pemerintah Kabupaten Bireuen dengan Menggunakan Analisis Highest and Best Use (HBU), Tesis, Program Pasca Sarjana Universita Gajah Mada.

Siregar, D. (2004). Manajemen Aset. Gramedia Pustaka Utama, IKPI, Jakarta. 